\title{
Blocking Cyclobutane Pyrimidine Dimers Formation by Steric Hindrance
}

\begin{abstract}
Victoria Vendrell-Criado, ${ }^{a}$ Virginie Lhiaubet-Vallet, ${ }^{a}$ Minoru Yamaji, ${ }^{b}$ M. Consuelo Cuquerella ${ }^{a}$ and Miguel A. Miranda ${ }^{a} *$

The efficiency of thymine (Thy) and uracil (Ura) to form cyclobutane pyrimidine dimers (CPDs) in solution, upon UV irradiation differs by one order of magnitude. This could to be partially related to the steric hindrance induced by the methyl at C5 in thymine. The aim of the present work is to establish the influence of a bulky moiety at this position on the photoreactivity of pyrimidines. With this purpose, photosensitization with benzophenone and acetone of a 5-tert-butyl uracil derivative (1) and the equivalent Thy (2) has been compared. Introduction of the tert-butyl group completely blocks CPDs formation. Moreover, the mechanistic insight obtained by laser flash photolysis is in accordance with the observed photoreactivity.
\end{abstract}

\section{Introduction}

Ultraviolet irradiation of DNA leads to formation of lesions such as cyclobutane pyrimidine dimers (CPDs). This hinders replication and transcription of the biomacromolecule, which may give rise to cytotoxicity and mutagenicity. ${ }^{1}$ Mechanistically, CPDs arise from a [2+2] photocycloaddition between two adjacent pyrimidines (Pyr) in the same DNA strand. $^{2,3}$

In solution, with monomeric derivatives, a fraction of Pyr is promoted to the triplet excited state $\left({ }^{3} \mathrm{Pyr}^{*}\right)$ upon light absorption and intersystem crossing (ISC). In turn, ${ }^{3} \mathrm{Pyr} *$ reacts with another Pyr in the ground state to give the final product (Scheme 1, pathway $a+b) .{ }^{4}$ In this context, the dimerization efficiency $\left(\phi_{D I M}\right)$ of thymine (Thy) compared to uracil (Ura) differs by one order of magnitude ( $\phi_{\text {DIM }}=0.0025$ and 0.019 , respectively). This variance has been rationalized in terms of a higher intersystem crossing quantum yield $\left(\phi_{\mathrm{ISC}}\right)$ and selfquenching rate constant $\left(k_{\mathrm{sQ}}\right)$ for Ura with respect to Thy $(0.40$ vs 0.18 and $2 \times 10^{9} \mathrm{M}^{-1} \mathrm{~s}^{-1}$ vs $6 \times 10^{8} \mathrm{M}^{-1} \mathrm{~s}^{-1}$, respectively). The

\footnotetext{
Instituto Universitario Mixto de Tecnología Química (UPV-CSIC), Universitat Politècnica de València, Av. Los Naranjos s/n 46022, Valencia, Spain. E-mail: mmiranda@qim.upv.es, mcuquere@itq.upv.es

${ }^{b .}$ Division of Molecular Science, Faculty of Science and Technology, Gunma University, Kiryu Gunma 376-8515, Japan.

+Electronic Supplementary Information (ESI) available: NMR spectra of synthesized and isolated compounds. See DOI: 10.1039/x0xx00000x
}

a)

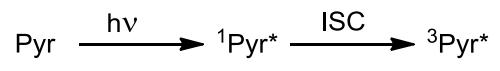

b)

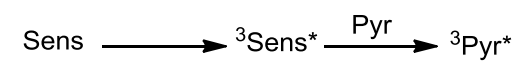

${ }^{3} \mathrm{Pyr}^{*}+\mathrm{Pyr} \longrightarrow \mathrm{Pyr}<>\mathrm{Pyr}$ (CPDs)

Scheme 1. Dimerization of pyrimidines to form cyclobutane pyrimidine dimers

disparity observed in the $k_{\mathrm{sQ}}$ in spite of the structural similarity between these two Pyr could rely on the steric hindrance associated with methyl substitution at C5; however this has not systematically been investigated.

Pyrimidine dimerization has also been studied after irradiation with UVA light in the presence of typical triplet sensitizers (Scheme 1, pathway $\left.a^{\prime}+b\right) .^{2,5-7}$

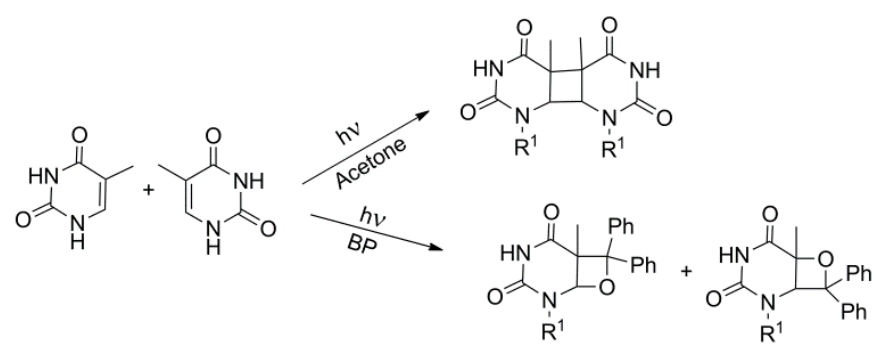

Scheme 2. Major photoproducts photosensitization of thymine derivatives by acetone and benzophenone 


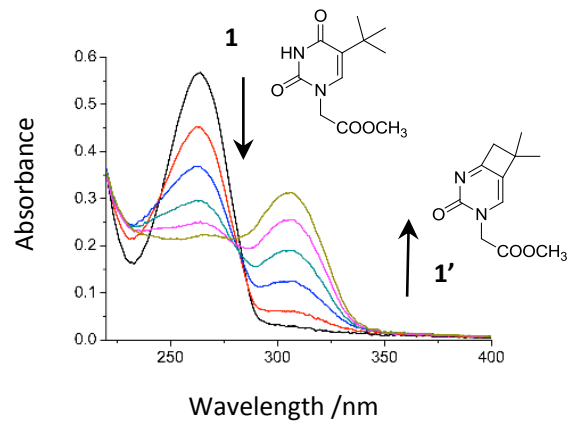

Fig 1. Spectral changes observed upon direct irradiation of $\mathbf{1}$ to give $\mathbf{1}$

Acetone photosensitization leads mainly to CPDs through triplet-triplet energy transfer (TTET, Scheme 2); however, benzophenone (BP) gives mainly rise to oxetanes formation as a result of a Paternò-Büchi reaction between the carbonyl moiety of BP and the C5-C6 double bond of the Pyr (Scheme 2). ${ }^{2,7-10}$ In this context, the aim of the present work is to determine the influence of steric hindrance on the photosensitized dimerization that leads to CPDs. With this purpose, the tert- butyl substituted uracil derivative $\mathbf{1}$ and its thymine analog 2, have been selected to investigate their photosensitization with $\mathrm{BP}\left(\mathrm{E}_{\mathrm{T}}=290 \mathrm{~kJ} \mathrm{~mol}^{-1}\right)$ and acetone $\left(\mathrm{E}_{\mathrm{T}}=\right.$ $332 \mathrm{~kJ} \mathrm{~mol}^{-1}$ ) looking at the kinetic aspects and also at the photoproducts distribution.

\section{Results and discussion}

\section{Direct Irradiation of 1}

Compound 1 displayed an ultraviolet spectrum in acetonitrile similar to that of the parent pyrimidine, with a maximum at $260 \mathrm{~nm}$. However, its direct irradiation differed from that of Thy. Absorption of light by 1 provoked a progressive decrease of the $260 \mathrm{~nm}$ peak, together with the appearance of a new one at $314 \mathrm{~nm}$. The presence of an isosbestic point at $280 \mathrm{~nm}$ indicated formation of one main photoproduct. This behavior was similar to that observed for the related compound 5-tertbutyl-2'-deoxyuridine that gives rise to the corresponding 1,2dihydrocyclobuta[d]pyrimidin-2-one through a Norrish-Yang photoreaction. ${ }^{11}$ Isolation and characterization of 1' (Figure 1) confirmed that under direct irradiation, 1 undergoes a NorrishYang process.
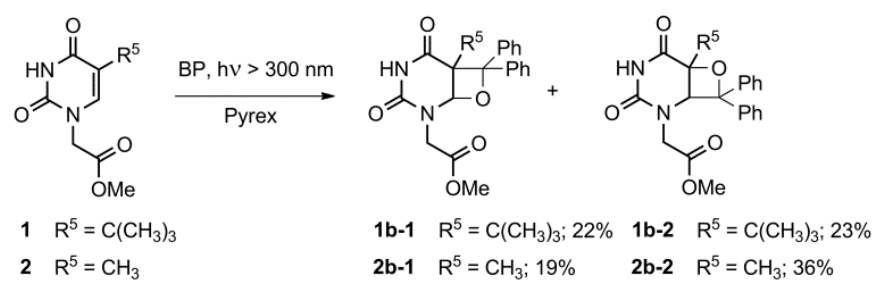

Scheme 3. Photoproducts isolated upon irradiation of $\mathbf{1}$ or $\mathbf{2}$ with benzophenone

\section{Steady State Photolysis in the Presence of Benzophenone}

An acetonitrile:water (11:3 v/v) solution of BP and $\mathbf{1}$ (or $\mathbf{2}$ ) at a 2:1 molar ratio was irradiated with lamps emitting mainly in the $310-390 \mathrm{~nm}$ range, the solvent removed under reduced pressure and the resulting mixture analyzed by NMR.

The ${ }^{1} \mathrm{H}-\mathrm{NMR}$ spectra of the reaction crudes clearly indicated that, under these conditions, the tert-butyl uracil $\mathbf{1}$ is by far less reactive than the reference thymine $\mathbf{2}$ (reaction rates of 0.5 vs $2.1 \times 10^{-6} \mathrm{M} \mathrm{s}^{-1}$, respectively. In both cases, the presence of two singlets located in the 5 to $6 \mathrm{ppm}$ range pointed to the formation of two oxetanes during the photoreaction. The proportion of each oxetane, determined from the integrals of the two singlets, was 50:50 for 1, and $35: 65$ for 2. Purification over silica column led to isolation of the regioisomeric oxetanes $\mathbf{1 b}-\mathbf{1}$ and $\mathbf{1 b}-\mathbf{2}$ or $\mathbf{2 b - 1}$ and $\mathbf{2 b - 2}$ (Scheme 3).

The oxetane regiochemistry was determined on the basis of the chemical shift of protons and carbons at $\mathrm{C} 5$ and $\mathrm{C} 6$. Thus,

$\Delta \delta$ (C5-C6) was 35 and 11 ppm for $\mathbf{2 b - 1}$ and $\mathbf{2 b - 2}$, respectively, indicating that $\mathbf{2 b - 1}$ corresponds to the oxetane in which oxygen is bonded to $\mathrm{C} 6$. The same trend, although less pronounced due to the contribution of the tert-butyl moiety, was observed for $\mathbf{1 b} \mathbf{- 1}$ and $\mathbf{1 b} \mathbf{b}$. The chemical shift observed for $\mathrm{H} 6$ was consistent with this assignment; this proton was less shielded in $\mathbf{1 b}-\mathbf{1}$ and $\mathbf{2 b - 1}(\delta=6.05$ and $5.37 \mathrm{ppm}$, respectively), than in $\mathbf{1 b - 2}$ and $\mathbf{2 b - 2},(\delta=5.18$ and $4.87 \mathrm{ppm}$, respectively). According to the product distribution, the bulky substituent at $\mathrm{C} 5$ does not have a strong influence on the regiochemistry of the reaction as it might be expected. Moreover, it is worth noting that no CPDs were found among the photoproducts, which means that the Paternò-Büchi reaction between $\mathrm{BP}$ and the Pyr predominates over [2+2] photocycloaddition. To get further insight into this behavior, similar experiments were run increasing the proportion of Pyr in the medium to favor TTET. ${ }^{8}$ Thus, solutions containing BP:1 (or 2) at 1:3 molar ratio were irradiated and the crude mixtures submitted to NMR. In the case of $\mathbf{1}$, the spectrum of the reaction crude, showed a similar photoproducts distribution and again evidenced the absence of CPDs even under these conditions. On the contrary, the irradiation performed with the reference compound $\mathbf{2}$ gave rise to additional photoproducts. Their isolation and characterization allowed identifying the cis-syn and trans-syn CPDs $\mathbf{2 c - 1}$ and 2c$\mathbf{2}$ (Figure 2). The $\mathbf{2 c - 2}$ stereochemistry was established on the basis of the NOE effect observed between the methyl $(\delta=1.65$ $\mathrm{ppm})$ and the methylene protons ( $\delta=4.99$ and $3.66 \mathrm{ppm})$. The CPD 2c-1 did not show such interaction (see NMR spectra of 2c-1 in ESI). 


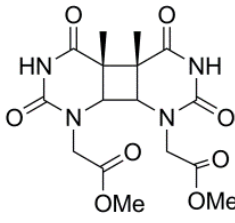

2c-1

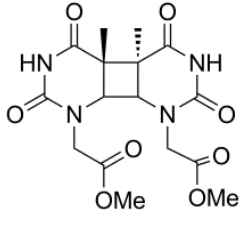

2c-2
Fig. 2. CPDs isolated after photosensitization of $\mathbf{2}$ by acetone<smiles>COC(=O)CC1C(=O)NC(=O)C2(C(C)(C)C)C1[C@H]1C(=O)NC(=O)N(CC(=O)OC)C12</smiles><smiles>COC(=O)CC1C(=O)NC(=O)C2(C(C)(C)C)C1C1C(=O)NC(=O)N(CC(=O)OC)C12</smiles>

$1 \underset{\text { Pyrex; } h v>300 \mathrm{~nm}}{\stackrel{\mathrm{CH}_{3} \mathrm{COCH}_{3}}{\longrightarrow}}$ 1c-1 (6\%)<smiles>COC(=O)CN1CC(CC(C)=O)(C(C)(C)C)C(=O)NC1=O</smiles>

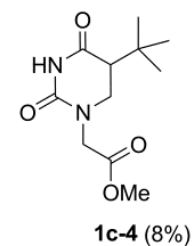

Scheme 4. Photoproducts obtained after photosensitization of $\mathbf{1}$ with acetone

\section{Steady State Photolysis in the Presence of Acetone}

Photolysis of 1 at $310-390 \mathrm{~nm}$ in an acetone: water solution (37:63 v/v) was performed during $18 \mathrm{~h}$ (72 \% conversion). Then, the solvent was removed under vacuum yielding a yellow oil. According to the analysis of the reaction crude made by ${ }^{1} \mathrm{H}-\mathrm{NMR}$, the progress of the reaction was very limited, but new photoproducts were formed. The main one was identified as the acetonyl derivative 1c-3 (Scheme 4), equivalent to the product previously found in thymidine photosensitization by acetone. ${ }^{2}$ In addition, two uracil/5-tertbutyl uracil heterodimers $\mathbf{1 c - 1}$ and $\mathbf{1 c - 2}$, together with photoproduct 1c-4, were isolated (Scheme 4). Clearly, 1c-1 and 1c-2 must arise from the Norrish type II photofragmentation reported for similar 5-tert-butyl uracils, followed by [2+2] photocycloaddition of the resulting (less hindered) dealkylated product with 1.

Remarkably, no homodimers were obtained with this photosensitization strategy in spite of the higher triplet energy of acetone. Conversely, irradiation of $\mathbf{2}$ under similar experimental conditions gave rise to homodimers $\mathbf{2 c - 1}$ and $\mathbf{2 c}$ 2 already obtained upon BP photosensitization. The results observed with $\mathbf{2}$ are consistent with those previously described for Thy and thymidine. ${ }^{2,5,7}$

\section{Laser Flash Photolysis}

To gain mechanistic insight into the process, laser flash photolysis experiments were performed. No transient signal was observed upon direct excitation of $\mathbf{1}$, more likely due to its very low triplet quantum yield and molar absorption coefficient. To circumvent this problem, ${ }^{3} \mathbf{1}^{*}$ was photosensitized by acetone upon excitation at $308 \mathrm{~nm}$. The

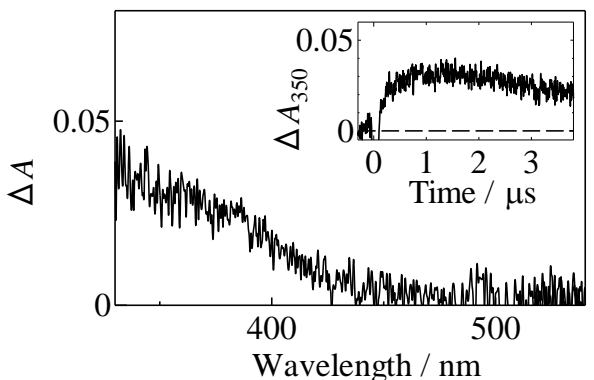

A

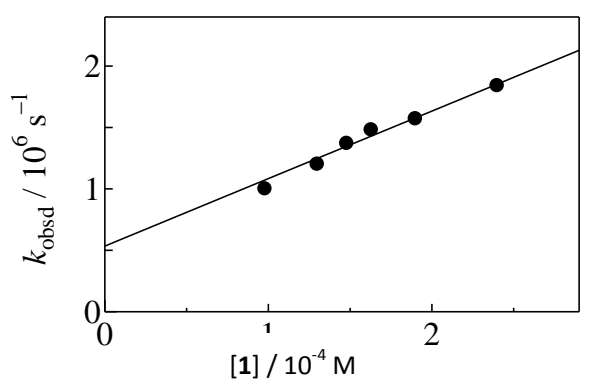

B

Fig. 3. A) Transient absorption spectrum at $1.3 \mu$ s obtained upon 308 $\mathrm{nm}$ laser pulsing in acetone $(0.6 \mathrm{M}) / \mathbf{1}(1.6 \mathrm{mM})$ in $\mathrm{ACN}$ at $295 \mathrm{~K}$. Inset; time profile at $350 \mathrm{~nm}$. B) Rise rates for ${ }^{3} 1^{*}$ plotted as a function of the concentration of 1
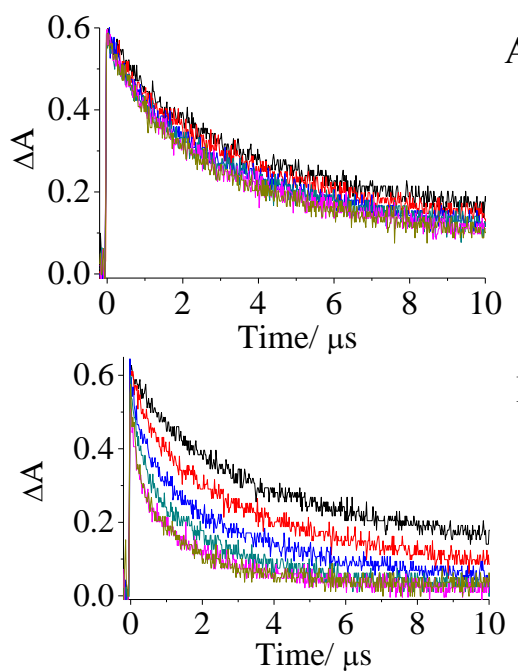

A

B

Fig. 4. Decay profiles of the signal at $530 \mathrm{~nm}$ obtained after laser excitation of $B P$ in the presence of increasing amounts of $A$ ) $\mathbf{1}$ (from 0 to $2.6 \mathrm{mM}$ ) and B) $\mathbf{2}$ (from 0 to $2.3 \mathrm{mM}$ )

transient absorption spectrum displayed a maximum at 350 profile at $350 \mathrm{~nm}$. The rise rate varied with the concentration of 1. From the slope of the linear plot $k_{\text {obsd }} v s$ [1] (Figure 3B), the quenching rate constant of triplet acetone by 1 was determined to be $k_{\mathrm{q}}=5.5 \times 10^{8} \mathrm{M}^{-1} \mathrm{~s}^{-1}$. This value indicates that $\mathrm{nm}$, very similar to that previously found for thymidine, ${ }^{12}$ where the absorbance change, $\Delta \mathrm{A}_{350}$ was as small as 0.03 (Figure $3 \mathrm{~A})$. Inset of Figure $3 \mathrm{~A}$ depicts the triplet formation the triplet energy of $\mathbf{1}$ is very close to that of acetone $\left(332 \mathrm{~kJ} \mathrm{~mol}^{-}\right.$ ${ }^{1}$ ), presumably within $4-8 \mathrm{~kJ} \mathrm{~mol}^{-1}$, according with Sandros' equation (1), which relates the energy transfer rate constant $\left(k_{\mathrm{ET}}\right)$ to the triplet energy gap between donor and acceptor: 


$$
k_{E T}=k_{D} \frac{1}{e^{-\Delta E / R T}+1}
$$

Where $k_{\mathrm{D}}$ is the diffusion rate constant in liquid solutions. ${ }^{13}$ Interaction of $\mathbf{1}$ with BP was also investigated by determining the quenching rate constant of ${ }^{3} \mathrm{BP} *$. With this purpose, BP solutions were prepared and increasing amounts of $\mathbf{1}$, and 2 for comparison, were added. As shown in Figure 4A, 1 barely quenches ${ }^{3} \mathrm{BP} *$, which is consistent with the low chemical reactivity exhibited by this compound upon photosensitization with BP. On the contrary, $\mathbf{2}$ displayed a significant quenching of ${ }^{3} \mathrm{BP}^{*}$ in accordance with its reactivity. A rate constant of 1.5 $\times 10^{8} \mathrm{M}^{-1} \mathrm{~s}^{-1}$ was obtained for the ${ }^{3} \mathrm{BP} * / 2$ interaction, which is in the same range as the one observed for thymidine. ${ }^{8,9}$

\section{Conclusions}

Replacement of the C5 thymine methyl group with a bulky tert-butyl substituent is associated with a marked decrease in the photoreactivity under triplet photosensitization conditions and completely blocks formation of CPDs.

\section{Experimental}

\section{Synthesis of 1 and 2}

Firstly, to a suspension of $13 \mathrm{~mL}$ of $\mathrm{H}_{2} \mathrm{O}$ containing 5-tert-butyl uracil $^{14}(1.0 \mathrm{~g}, 6.0 \mathrm{mmol})$ an aqueous $2 \mathrm{~N} \mathrm{KOH}(13 \mathrm{~mL})$ solution was added. The mixture was stirred at room temperature until a clear solution was obtained. Ethyl bromoacetate ( 2 eq) was added and then heated to reflux overnight. The cold reaction mixture was acidified with conc. $\mathrm{HCl}$ until $\mathrm{pH} 1$ and the crystallized product filtered, washed with cold $1 \mathrm{~N} \mathrm{HCl}$ and water and dried in vacuo to give tert-butyl uracil-1-acetic acid: (0.8 g, 59\%). ${ }^{1} \mathrm{H}$ NMR (300 MHz, DMSO-d $\left.\mathrm{d}_{6}\right), \delta_{\mathrm{H}}: 11.18(\mathrm{~s}, 1 \mathrm{H})$, $7.36(\mathrm{~s}, 1 \mathrm{H}), 4.39(\mathrm{~s}, 2 \mathrm{H}), 1.19(\mathrm{~s}, 9 \mathrm{H}) .{ }^{13} \mathrm{C} \mathrm{NMR}(75 \mathrm{MHz}$, DMSO- $\mathrm{d}_{6}$ ): $169.8,163.1,150.8,140.6,119.8,49.0,32.5,28.6$. HRMS (ESI): $\mathrm{m} / \mathrm{z}$ calcd for $\mathrm{C}_{10} \mathrm{H}_{15} \mathrm{~N}_{2} \mathrm{O}_{4}\left[\mathrm{M}+\mathrm{H}^{+}\right] 227.1032$, found $\left[\mathrm{M}+\mathrm{H}^{+}\right] 227.1039$.

Then, to a stirred solution of this compound $(0.2 \mathrm{~g}, 1.1 \mathrm{mmol})$ or thymine-1-acetic acid $(0.2 \mathrm{~g}, 0.9 \mathrm{mmol})$ in $\mathrm{MeOH}(5 \mathrm{~mL})$ $\mathrm{H}_{2} \mathrm{SO}_{4}$ was added $(0.5 \mathrm{~mL})$. The reaction mixtures were heated to reflux overnight. The solvent was evaporated under pressure. The solids were dissolved in AcOEt, washed in brine $(3 \mathrm{x})$ and dried over $\mathrm{MgSO}_{4}$. The compounds were obtained as white solids 1 (0.2 g, 90\%) or $2^{15}(0.2 \mathrm{~g}, 92 \%)$.

Compound 1. ${ }^{1} \mathrm{H}$ NMR (300 MHz, DMSO- $\left.\mathrm{d}_{6}\right), \delta_{\mathrm{H}}: 11.26(\mathrm{~s}, 1 \mathrm{H})$, $7.40(\mathrm{~s}, 1 \mathrm{H}), 4.54(\mathrm{~s}, 2 \mathrm{H}), 3.69(\mathrm{~s}, 3 \mathrm{H}), 1.21(\mathrm{~s}, 9 \mathrm{H}) .{ }^{13} \mathrm{C}$ NMR $(75$ MHz, DMSO- $\mathrm{d}_{6}$ ): 168.8, 163.0, 150.6, 140.4, 120.2, 52.2, 48.6, 32.5, 28.6. HRMS (ESI): $\mathrm{m} / \mathrm{z}$ calcd for $\mathrm{C}_{11} \mathrm{H}_{17} \mathrm{~N}_{2} \mathrm{O}_{4}\left[\mathrm{M}+\mathrm{H}^{+}\right]$ 241.1181, found $\left[\mathrm{M}+\mathrm{H}^{+}\right] 241.1188$.

Compound 2. ${ }^{1} \mathrm{H}$ NMR (300 MHz, DMSO-d $\left.\mathrm{d}_{6}\right), \delta_{\mathrm{H}}: 11.42(\mathrm{~s}, 1 \mathrm{H})$, $7.51(\mathrm{~s}, 1 \mathrm{H}), 4.49(\mathrm{~s}, 2 \mathrm{H}), 3.70(\mathrm{~s}, 3 \mathrm{H}), 1.77(\mathrm{~s}, 3 \mathrm{H})$. HRMS (ESI): $\mathrm{m} / \mathrm{z}$ calcd for $\mathrm{C}_{8} \mathrm{H}_{11} \mathrm{~N}_{2} \mathrm{O}_{4}\left[\mathrm{M}+\mathrm{H}^{+}\right]$199.0717, found $\left[\mathrm{M}+\mathrm{H}^{+}\right]$ 199.0719 .

\section{Irradiation Procedures}

Irradiations were performed using a multilamp photoreactor using lamps emitting at $254 \mathrm{~nm}$ through quartz or in the 310$390 \mathrm{~nm}$ range (with a maximum at $350 \mathrm{~nm}$ ) through pyrex. All the solutions were bubbled with $\mathrm{N}_{2}$ prior to light exposure.

Isolation and Identification of $\mathbf{1}^{\prime}$. Compound $\mathbf{1}(0.2 \mathrm{~g}, 0.9$ $\mathrm{mmol}$ ) was dissolved in acetonitrile and irradiated at $254 \mathrm{~nm}$ through quartz. The progress of the reaction was monitored by UV-Vis. When the UV band with $\lambda_{\max } 314 \mathrm{~nm}$, associated with $1^{\prime}$ reached its maximum, ( $4 \mathrm{~h}$ irradiation) the solvent was evaporated under vacuum.

${ }^{1} \mathrm{H}$ NMR (300 MHz, DMSO-d $\left.\mathrm{d}_{6}\right), \delta_{\mathrm{H}}: 7.70(\mathrm{~s}, 1 \mathrm{H}), 4.58(\mathrm{~s}, 2 \mathrm{H})$, $3.70(\mathrm{~s}, 3 \mathrm{H}), 3.12(\mathrm{~s}, 2 \mathrm{H}), 1.40(\mathrm{~s}, 6 \mathrm{H}) .{ }^{13} \mathrm{C}$ NMR $(75 \mathrm{MHz}$, DMSO-d $\mathrm{d}_{6}$ ): 181.7, 168.5, 157.2, 139.7, 128.4, 54.5, 52.2, 51.9, 50.0, 26.7. HRMS (ESI): $\mathrm{m} / \mathrm{z}$ calcd for $\mathrm{C}_{11} \mathrm{H}_{15} \mathrm{~N}_{2} \mathrm{O}_{3}\left[\mathrm{M}+\mathrm{H}^{+}\right]$ 223.1075, found $\left[\mathrm{M}+\mathrm{H}^{+}\right]$223.1083.

Isolation and Identification of Photoproducts Obtained upon Irradiation of 1 and $\mathbf{2}$ with BP An acetonitrile:water (11:3 v/v) solution of $B P(28 \mathrm{mM})$ and 1 (or 2 ) at a 2:1 molar ratio was irradiated. Purification of photoproducts from $\mathbf{1}$ and $\mathbf{2}$ was achieved over silica gel column using hexane:ethyl acetate 60:40 as eluent. Two fractions containing the two regioisomers of oxetanes were collected and the solvent evaporated.

Oxetane 1b-1: ${ }^{1} \mathrm{H}$ NMR (300 MHz, CD $\left.{ }_{3} \mathrm{OD}\right), \delta_{\mathrm{H}}: 7.82(\mathrm{~d}, \mathrm{~J}=9 \mathrm{~Hz}$, $2 \mathrm{H}), 7.62(\mathrm{~d}, \mathrm{~J}=9 \mathrm{~Hz}, 2 \mathrm{H}), 7.43-7.13(\mathrm{~m}, 6 \mathrm{H}), 6.05(\mathrm{~s}, 1 \mathrm{H}), 4.64$ (d, J = $18 \mathrm{~Hz}, 1 \mathrm{H}), 4.29(\mathrm{~d}, \mathrm{~J}=18 \mathrm{~Hz}, 1 \mathrm{H}), 3.77(\mathrm{~s}, 3 \mathrm{H}), 1.03(\mathrm{~s}$, 9H). ${ }^{13} \mathrm{C}$ NMR (75 MHz, CD $\left.{ }_{3} \mathrm{OD}\right): 171.5,171.0,153.5,144.3$, 143.0, 129.3, 128.9, 128.7, 128.4, 128.2, 127.5, 90.6, 86.1, 67.7, 52.8, 47.4, 36.6, 27.8. HRMS (ESI): $\mathrm{m} / \mathrm{z}$ calcd for $\mathrm{C}_{24} \mathrm{H}_{26} \mathrm{~N}_{2} \mathrm{O}_{5} \mathrm{Na}\left[\mathrm{M}+\mathrm{Na}^{+}\right]$445.1763, found $\left[\mathrm{M}+\mathrm{Na}^{+}\right]$445.1735.

Oxetane 1b-2: ${ }^{1} \mathrm{H}$ NMR (300 MHz, CD $\left.\mathrm{CD}_{3} \mathrm{OD}\right) \delta_{\mathrm{H}}$ : 7.43-7.20 (m, $10 \mathrm{H}), 5.18(\mathrm{~s}, 1 \mathrm{H}), 4.64(\mathrm{~d}, \mathrm{~J}=18 \mathrm{~Hz}, 1 \mathrm{H}), 4.06(\mathrm{~d}, \mathrm{~J}=18 \mathrm{~Hz}$, $1 \mathrm{H}), 3.81(\mathrm{~s}, 3 \mathrm{H}), 1.13(\mathrm{~s}, 9 \mathrm{H}) .{ }^{13} \mathrm{C}$ NMR $\left(75 \mathrm{MHz}, \mathrm{CD}_{3} \mathrm{OD}\right)$ : $172.2,170.7,153.5,145.4,141.2,129.7,129.5,128.9,128.8$, 126.7, 125.8, 92.4, 85.1, 62.1, 53.0, 49.9, 36.9, 24.9. HRMS (ESI): $\mathrm{m} / \mathrm{z}$ calcd for $\mathrm{C}_{24} \mathrm{H}_{26} \mathrm{~N}_{2} \mathrm{O}_{5} \mathrm{Na}\left[\mathrm{M}+\mathrm{Na}^{+}\right]$445.1739, found $\left[\mathrm{M}+\mathrm{Na}^{+}\right]$445.1709.

Oxetane 2b-1: ${ }^{1} \mathrm{H}$ NMR (300 MHz, $\left.\mathrm{CD}_{3} \mathrm{CN}\right), \delta_{\mathrm{H}}: 8.39(\mathrm{~s}, 1 \mathrm{H})$, 7.61 - $7.54(\mathrm{~m}, 4 \mathrm{H}), 7.42-7.37(\mathrm{~m}, 2 \mathrm{H}), 7.35-7.18(\mathrm{~m}, 4 \mathrm{H})$, $5.37(\mathrm{~s}, 1 \mathrm{H}), 4.32(\mathrm{~d}, \mathrm{~J}=18 \mathrm{~Hz}, 1 \mathrm{H}), 4.13(\mathrm{~d}, \mathrm{~J}=18 \mathrm{~Hz}, 1 \mathrm{H}), 3.71$ (s, 3H), 1.39 (s, 3H). ${ }^{13} \mathrm{C}$ NMR $\left(75 \mathrm{MHz}, \mathrm{CD}_{3} \mathrm{CN}\right): 171.0,170.3$, 152.2, 143.5, 142.6, 129.6, 129.1, 128.9, 128.8, 126.7, 90.3, 89.7, 54.7, 53.4, 47.3, 20.3. HRMS (ESI): $\mathrm{m} / \mathrm{z}$ calcd for $\mathrm{C}_{21} \mathrm{H}_{21} \mathrm{~N}_{2} \mathrm{O}_{5}\left[\mathrm{M}+\mathrm{H}^{+}\right]$381.1450, found $\left[\mathrm{M}+\mathrm{H}^{+}\right]$381.1441.

Oxetane 2b-2: ${ }^{1} \mathrm{H}$ NMR $\left(400 \mathrm{MHz}, \mathrm{CD}_{3} \mathrm{CN}\right), \delta_{\mathrm{H}}: 8.14(\mathrm{~s}, 1 \mathrm{H})$, 7.39-7.28 (m, 10H), $4.87(\mathrm{~s}, 1 \mathrm{H}), 4.49(\mathrm{~d}, \mathrm{~J}=16 \mathrm{~Hz}, 1 \mathrm{H}), 3.77$ (d, $\mathrm{J}=16 \mathrm{~Hz}, 1 \mathrm{H}), 3.72(\mathrm{~s}, 3 \mathrm{H}), 1.67(\mathrm{~s}, 3 \mathrm{H}) .{ }^{13} \mathrm{C} N M R(75 \mathrm{MHz}$, $\left.\mathrm{CD}_{3} \mathrm{CN}\right): 170.5,169.6,151.6,144.8,140.1,129.1,128.9,128.5$, 128.5, 126.3, 91.8, 77.3, 66.2, 52.7, 48.3, 23.3. HRMS (ESI): $\mathrm{m} / \mathrm{z}$ calcd for $\mathrm{C}_{21} \mathrm{H}_{20} \mathrm{~N}_{2} \mathrm{O}_{5} \mathrm{Na}\left[\mathrm{M}+\mathrm{Na}^{+}\right]$403.1270, found $\left[\mathrm{M}+\mathrm{Na}^{+}\right]$ 403.1255 .

Isolation and Identification of the Products Obtained Upon Photosensitization of $\mathbf{1 b}$ and $\mathbf{2} \mathbf{b}$ in the Presence of Acetone Photoproducts obtained from 1. A solution of 1 or 2 (4.5 mM) in an acetone:water $(37: 63 \mathrm{v} / \mathrm{v})$ solution was irradiated 
through pyrex with lamps emitting in the 310-390 $\mathrm{nm}$ range (with a maximum at $350 \mathrm{~nm}$ ). The crude reaction was submitted to reverse phase HPLC, and the photoproducts were isolated using a 60:40 mixture of a $25 \mathrm{mM}$ ammonium formiate aqueous solution and methanol as eluent. The proportion of methanol was linearly increased from 40 to $70 \%$ within $35 \mathrm{~min}$. Elution of the products was monitored at 220 $\mathrm{nm}$. According to the obtained mass $70 \%$ of 1 was consumed during the irradiation.

Photoproduct 1c-1. ${ }^{1} \mathrm{H}$ NMR (400 MHz, $\mathrm{CDCl}_{3}$ ), $\delta \mathrm{H}: 4.97$ (d, J = $0.8 \mathrm{~Hz}, 1 \mathrm{H}), 4.93(\mathrm{~d}, \mathrm{~J}=0.8 \mathrm{~Hz}, 1 \mathrm{H}), 4.34(\mathrm{~d}, \mathrm{~J}=8 \mathrm{~Hz}, 1 \mathrm{H}), 4.09$ $(\mathrm{d}, \mathrm{J}=8,1 \mathrm{H}), 3.82-3.65(\mathrm{~s}+\mathrm{m}, 6+3 \mathrm{H}), 1.16(\mathrm{~s}, 9 \mathrm{H}) .{ }^{13} \mathrm{C}$ NMR $(75$ $\mathrm{MHz}, \mathrm{CDCl}_{3}$ ): 169.6, 169.5, 168.3, 166.3, 151.3, 150.9, 62.7, 52.5, 50.7, 50.4, 46.9, 46.3, 41.1, 35.2, 29.7. HRMS (ESI): $\mathrm{m} / \mathrm{z}$ calcd for $\mathrm{C}_{18} \mathrm{H}_{25} \mathrm{~N}_{4} \mathrm{O}_{8}\left[\mathrm{M}+\mathrm{H}^{+}\right]$425.1659, found $\left[\mathrm{M}+\mathrm{H}^{+}\right] 425.1672$. Photoproduct 1c-2. ${ }^{1} \mathrm{H}$ NMR $\left(400 \mathrm{MHz}, \mathrm{CD}_{3} \mathrm{CN}\right), \delta_{\mathrm{H}}: 4.45(\mathrm{~d}, \mathrm{~J}=$ $16 \mathrm{~Hz}, 1 \mathrm{H}), 4.11(\mathrm{~m}, 3 \mathrm{H}), 3.84(\mathrm{~d}, \mathrm{~J}=20 \mathrm{~Hz}, 1 \mathrm{H}), 3.72(\mathrm{~s}, 3 \mathrm{H})$, $3.67(\mathrm{~s}, 3 \mathrm{H}), 3.57(\mathrm{~d}, \mathrm{~J}=16 \mathrm{~Hz}, 1 \mathrm{H}), 3.29(\mathrm{~d}, \mathrm{~J}=8,1 \mathrm{H}), 1.11(\mathrm{~s}$, $9 \mathrm{H}) .{ }^{13} \mathrm{C}$ NMR $(75 \mathrm{MHz}, \mathrm{CD} 3 \mathrm{CN}): 170.2,169.5,166.9,153.5$, 152.3, 61.7, 55.6, 55.4, 52.4, 48.0, 47.6, 37.3, 35.4, 25.9. HRMS (ESI): $\mathrm{m} / \mathrm{z}$ calcd for $\mathrm{C}_{18} \mathrm{H}_{25} \mathrm{~N}_{4} \mathrm{O}_{8}\left[\mathrm{M}+\mathrm{H}^{+}\right]$425.1658, found $\left[\mathrm{M}+\mathrm{H}^{+}\right]$ 425.1672.

Photoproduct 1c-3. ${ }^{1} \mathrm{H}$ NMR (300 MHz, $\left.\mathrm{CD}_{3} \mathrm{OD}\right), \delta_{\mathrm{H}}: 4.26$ (d, J = $15 \mathrm{~Hz}, 1 \mathrm{H}), 4.02(\mathrm{~d}, \mathrm{~J}=18 \mathrm{~Hz}, 1 \mathrm{H}), 3.74(\mathrm{~s}, 3 \mathrm{H}), 3.71(\mathrm{~d}, \mathrm{~J}=6 \mathrm{~Hz}$, $1 \mathrm{H}), 3.40(\mathrm{~d}, \mathrm{~J}=12.0 \mathrm{~Hz}, 1 \mathrm{H}), 3.26(\mathrm{~s}, 1 \mathrm{H}), 2.61(\mathrm{~d}, \mathrm{~J}=18 \mathrm{~Hz}$, $1 \mathrm{H}), 2.12(\mathrm{~s}, 3 \mathrm{H}), 1.05(\mathrm{~s}, 9 \mathrm{H}) .{ }^{13} \mathrm{C}$ NMR (75 MHz, CD $\left.{ }_{3} \mathrm{OD}\right)$ : 208.8, 175.0, 170.8, 155.1, 52.6, 50.4, 49.1, 46.1, 37.4, 30.3, 26.9. HRMS (ESI): $\mathrm{m} / \mathrm{z}$ calcd for $\mathrm{C}_{14} \mathrm{H}_{23} \mathrm{~N}_{2} \mathrm{O}_{5}\left[\mathrm{M}+\mathrm{H}^{+}\right]$299.1607, found $\left[\mathrm{M}+\mathrm{H}^{+}\right]$299.1601.

Photoproduct 1c-4. ${ }^{1} \mathrm{H}$ NMR (400 MHz, $\left.\mathrm{CDCl}_{3}\right), \delta_{\mathrm{H}}: 4.28$ (d, J = $16 \mathrm{~Hz}, 1 \mathrm{H}), 4.05(\mathrm{~d}, \mathrm{~J}=20 \mathrm{~Hz}, 1 \mathrm{H}), 3.77(\mathrm{~s}, 3 \mathrm{H}), 3.56$ (dd, $\mathrm{J}=16$ $\mathrm{Hz}, 2 \mathrm{H}), 2.47(\mathrm{t}, \mathrm{J}=8 \mathrm{~Hz}, 1 \mathrm{H}), 1.12(\mathrm{~s}, 9 \mathrm{H}) .{ }^{13} \mathrm{C} \mathrm{NMR}(75 \mathrm{MHz}$, CDCl3): 169.6, 168.1, 151.7, 51.4, 48.7, 47.5, 44.7, 31.9, 27.2. HRMS (ESI): $\mathrm{m} / \mathrm{z}$ calcd for $\mathrm{C}_{11} \mathrm{H}_{18} \mathrm{~N}_{2} \mathrm{O}_{2}\left[\mathrm{M}+\mathrm{H}^{+}\right]$243.1345, found $\left[\mathrm{M}+\mathrm{H}^{+}\right] 243.1361$.

Photoproducts obtained from 2. Photoproducts $\mathbf{2 c - 1}$ and $\mathbf{2 c - 2}$ were isolated by reverse phase HPLC using an 80:20 mixture of a $25 \mathrm{mM}$ ammonium formiate aqueous solution and methanol. The proportion of methanol was linearly increased from 20 to $40 \%$ within $35 \mathrm{~min}$. Elution of the products was monitored at $220 \mathrm{~nm}$.

Photoproduct 2c-1. ${ }^{1} \mathrm{H}$ NMR $\left(300 \mathrm{MHz}, \mathrm{CD}_{3} \mathrm{CN}\right) \delta_{\mathrm{H}}: 4.30(\mathrm{~d}, \mathrm{~J}=$ $15 \mathrm{~Hz}, 2 \mathrm{H}), 3.92(\mathrm{~s}, 2 \mathrm{H}), 3.70-3.64(\mathrm{~d}+\mathrm{s}, 2+6 \mathrm{H}), 1.43(\mathrm{~s}, 6 \mathrm{H}) .{ }^{13} \mathrm{C}$ NMR $\left(75 \mathrm{MHz}, \mathrm{CDCl}_{3}\right)$ : 171.3, 170.0, 153.1, 61.1, 52.9, 48.4, 48.0, 19.0. HRMS (ESI): $\mathrm{m} / \mathrm{z}$ calcd for $\mathrm{C}_{16} \mathrm{H}_{21} \mathrm{~N}_{4} \mathrm{O}_{8}\left[\mathrm{M}+\mathrm{H}^{+}\right]$ 397.1359, found $\left[\mathrm{M}+\mathrm{H}^{+}\right] 397.1342$.

Photoproduct 2c-2. ${ }^{1} \mathrm{H}$ NMR $\left(300 \mathrm{MHz}, \mathrm{CDCl}_{3}\right), \delta_{\mathrm{H}}: 4.99(\mathrm{~d}, \mathrm{~J}=$ $18 \mathrm{~Hz}, 2 \mathrm{H}), 3.77(\mathrm{~s}, 6 \mathrm{H}), 3.63(\mathrm{~d}, \mathrm{~J}=18 \mathrm{~Hz}, 2 \mathrm{H}), 3.52(\mathrm{~s}, 2 \mathrm{H})$, $1.65(\mathrm{~s}, 6 \mathrm{H}) .{ }^{13} \mathrm{C} \mathrm{NMR}\left(75 \mathrm{MHz}, \mathrm{CDCl}_{3}\right): 170.2,169.5,151.1$, 63.4, 52.6, 48.8, 47.1, 24.7. HRMS (ESI): $\mathrm{m} / \mathrm{z}$ calcd for $\mathrm{C}_{16} \mathrm{H}_{21} \mathrm{~N}_{4} \mathrm{O}_{8}\left[\mathrm{M}+\mathrm{H}^{+}\right]$397.1359, found $\left[\mathrm{M}+\mathrm{H}^{+}\right]$397.1345.

UPLC-MS MS Analysis. Liquid Chromatography was performed on an ACQUITY UPLC system (Waters Corp.) with a conditioned autosampler at $4{ }^{\circ} \mathrm{C}$. The separation was carried out on an ACQUITY UPLC BEH C18 column $(50 \mathrm{~mm} \times 2.1 \mathrm{~mm}$ i.d., $1.7 \mu \mathrm{m})$.
The Waters ACQUITY'M XevoQToF Spectrometer (Waters Corp.) was connected to the UPLC system via an electrospray ionization (ESI) interface. The ESI source was operated in positive ioniza-tion mode with the capillary voltage at $1.5 \mathrm{kV}$.

Laser Flash photolysis. A pulsed Nd:YAG laser system instrument, using $355 \mathrm{~nm}$ as excitation wavelength or a $\mathrm{Xe} / \mathrm{HCl}$ Excimer laser $\left(\lambda_{\text {exc }}=308 \mathrm{~nm}\right)$ both with a duration of each pulse of $10 \mathrm{~ns}$ were used. The apparatus consisted of the pulsed laser, the Xe lamp, a monochromator and a photomultiplier. The output signal from the oscilloscope was transferred to a personal computer. Quartz cells of $1 \mathrm{~cm}$ optical path length were employed for the measurements.

The triplet excited state absorption spectrum of 1 (1.6 mM) in acetonitrile was registered using acetone $(0.6 \mathrm{M})$ as photosensitizer upon excitation at $308 \mathrm{~nm}$. The absorbance of the sample at this wavelength was 1.6 .

For quenching experiments 1 (from 0 to $2.6 \mathrm{mM}$ ) or $\mathbf{2}$ (from 0 to $2.3 \mathrm{mM}$ ) were added to a BP solution in acetonitrile with an absorption of 0.3 at $308 \mathrm{~nm}$, and monitored at $530 \mathrm{~nm}$.

\section{Acknowledgements}

Financial support by the Spanish Government (CTQ201232621, CTQ2015-70164-P and contract JAE-Predoc 2011-00740 to V.V.-C.) and the Generalitat Valenciana (PROMETEOII/2013/005) is gratefully acknowledged.

\section{References}

1. S. Mouret, C. Baudouin, M. Charveron, A. Favier, J. Cadet and T. Douki, Proc. Natl. Acad. Sci. USA, 2006, 103, 13765-13770.

2. J. Cadet, L. Voituriez, F. E. Hruska, L.-S. Kan, F. A. A. de Leeuw and C. Altona, Can. J. Chem., 1985, 63, 2861-2868.

3. J. Cadet, S. Mouret, J.-L. Ravanat and T. Douki, Photochem. Photobiol., 2012, 88, 1048-1065.

4. P. J. Wagner and D. J. Bucheck, J. Am. Chem. Soc., 1970, 92, 181-185.

5. T. Delatour, T. Douki, C. D'Ham and J. Cadet, J. Photochem. Photobiol. B: Biol., 1998, 44, 191-198.

6. M. C. Cuquerella, V. Lhiaubet-Vallet, F. Bosca and M. A. Miranda, Chem. Sci., 2011, 2, 1219-1232.

7. M. C. Cuquerella, V. Lhiaubet-Vallet, J. Cadet and M. A. Miranda, Acc. Chem. Res., 2012, 45, 1558-1570.

8. S. Encinas, N. Belmadoui, M. J. Climent, S. Gil and M. A. Miranda, Chem. Res.Toxicol., 2004, 17, 857-862.

9. V. Lhiaubet-Vallet, S. Encinas and M. A. Miranda, J. Am. Chem. Soc., 2005, 127, 12774-12775.

10. Q. H. Song, W. Z. Lin, S. D. Yao and N. Y. Lin, J. Photochem. Photobiol. A: Chem., 1998, 114, 181-184.

11. I. Basnak, D. McKinnell, N. Spencer, A. Balkan, P. R. Ashton and R. T. Walker, J. Chem. Soc., Perkin Trans. 1, 1997, 121-126. 12. I. G. Gut, P. D. Wood and R. W. Redmond, J. Am. Chem. Soc., 1996, 118, 2366-2373.

13. K. Sandros, Acta Chem. Scand., 1964, 18, 2355-2374.

14. I. Basnak, A. Balkan, P. L. Coe and R. T. Walker, Nucleosides \& Nucleotides, 1994, 13, 177-196. 
15. K.-H. Lee, Y.-S. Wu and I. H. Hall, J. Med. Chem., 1977, 20,

911-914.

6 | J. Name., 2012, 00, 1-3

This journal is (C) The Royal Society of Chemistry 20xx 